Vidyodaya J., Sci., (1992) Vol 4, No. 1,pp: $107-115$

\title{
SPECIES COMPOSITION, DISTRIBUTION AND ECONOMIC IMPORTANCE OF FISHES IN THE BOLGODA LAGOON
}

\author{
J. Jinadasa', H. D. S. Jayantha ${ }^{2}$ and W. V. J. Percra ${ }^{3}$ \\ 1,2. Department of Zoology, \\ University of Sri Jayewardenepura, \\ Nugegoda, Sri Lanka. \\ 3. Department of Zoology, \\ Open University, \\ Nawala, Sri Lanka.
}

Received on : $11-11-1991$

Accepted on : $15-07-1992$

\begin{abstract}
There are 55 species of fin fishes belonging to 33 families in the Bolgoda Lagoon, of which about 30 are commercially important. Sardinella melanura, Caranx sansun, Leognathus. sp, Mugil cephalus, Etroplus suratensis and Trachysurus cuelus are the dominant species. The mean annual fin fish production is 30 $\mathrm{mt} /$ year and it is on the decline.
\end{abstract}

Key words: Bolgoda Lagoon, Fin Fish, Annual Production.

\section{Introduction:}

Bellanwila-Attidiya marshes have been declared bird and wildlife sanctury. Those marshes serve as the primary drainage area for the Bolgoda Lagoon system which consists of southern Bolgoda lake, northern Bolgoda Lake, Bolgoda Ganga, Veras ganga and Panadura ganga (Fig. 1).

The Ratmalana Industrial Zone (RIZ) is located in close proximity to these marshes. At present some effluents, discharged by the factories, pass through the marshes and finally reach the head end of the Bolgoda Lagoon system. This could possibly have an impact on the fin fish fauna of the lagoon in the future. In order to assess such an impact, it is necessary to understand its present faunal composition. There is no published information on the species composition and the diversity of fin fish of the Bolgoda Lagoon system. A comprehensive check list of fishes of the Bellanwila-Attidiya marshes, however, have been reported for the period 1980-87 (Nalinda, 1987), where he listed 33 species of fin fishes for the above marshes. 
The purpose of the present study was to prepare a check list of species present, their broad distribution pattern and to indicate whether or not they are commercially important.

\section{Materials and methods}

The study was carried out from March 1979 to June 1991. Sampling was done at Katubedda, Deliara, Diggala, Kcspelana, Molpe, Horetuduwa,

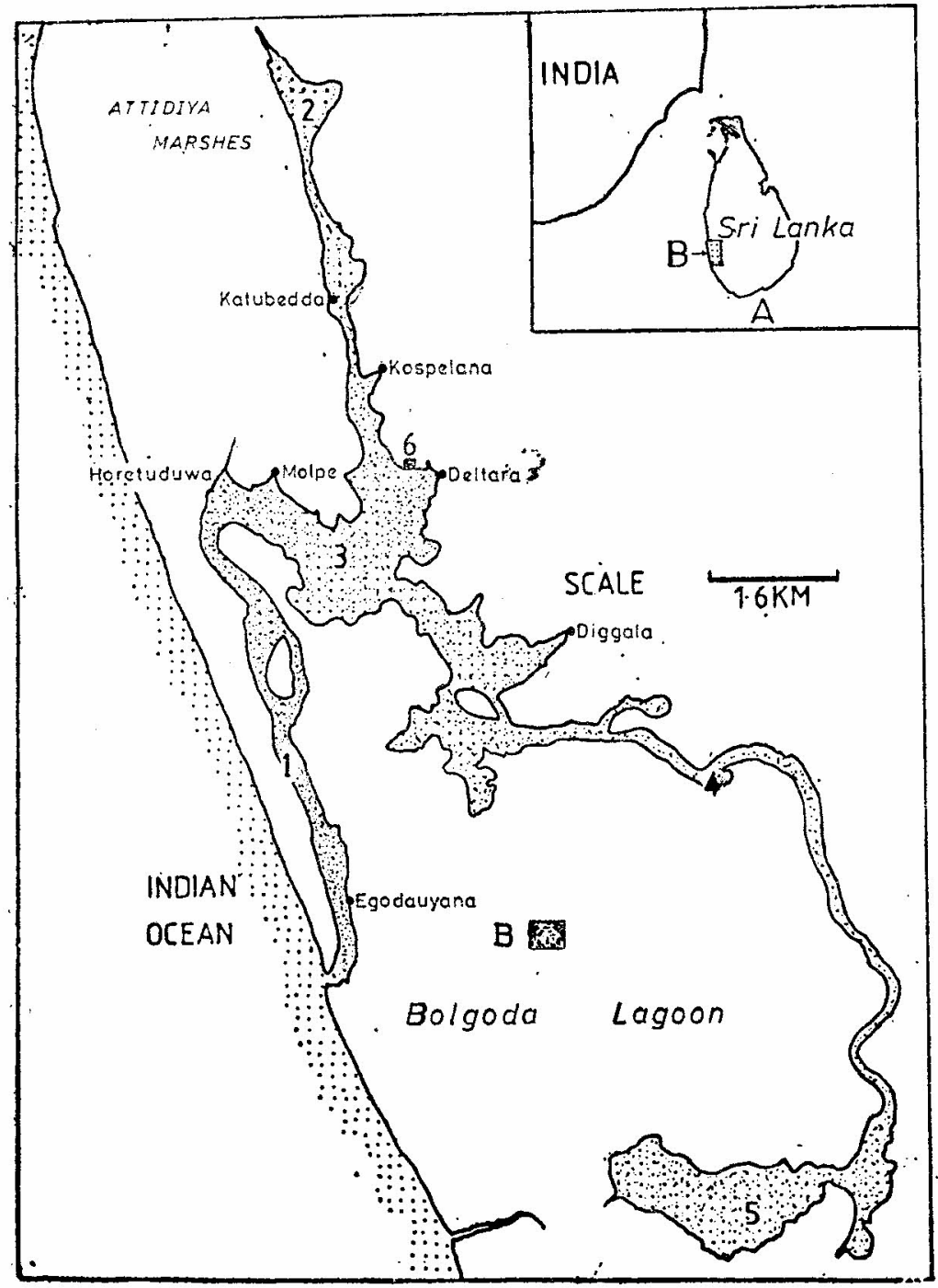

Fig. 1 1. Map of Bolgoda Lagoon indicating sampling stations,

1. Panadura Ganga, 2. Veras Ganga, 3. Northern Bolgoda Lake,

4. Bolgoda Ganga, 5. Southern Bolgoda Lake, B. Location of the study area in Sri Lanka. 
and Egodauyana. Commercial fish catches of traps, encircling nets, beach seines and gill nets wore sampled biweekly. Identification were made according to Munro (1955) and Fischer and Whitehead (1974). Parameters such as salinity and temperature were also monitored during the above period in an attempt to understand the hydrobiology, primary production and fishery of the Bolgoda lagoon system. These findings would be reported separately.

\section{Results:}

The results indicate that there are 55 species of fish in the Bolgoda Lagoon of which seven are distributed in the upper part, sixteen in the lower part, five in the upper and middle part, eleven in the lower and middle part and six to the entire lagoon respectively (Table. 1). The total number of commercially important species varied from 27 at Egoda-Uyana, near the mouth of the Lagoon to 20 at Katubedda, near the head end of the Lagoon. The highest number 30, was recorded at Deltara area, in the northern Bolgoda lake, where the water is blackish. Dominant species of fishes such as Sardinella melanura, Caranx sansun, Leiognathus smithursti, L. splendens, L. daura, Secutor ruconi:us, Elops machinata and $S$. insidinator are confined to the lower part of the Lagoon and contributo to abcut $35 \%$ of the total fin fish catch. Species such as Mugil cephalus and L. dussumieri are mostly found around the middle region of the Lagoon and contribute to about $12 \%$ of the total catch. Etroplus suratensis, L. brevirostris, Gazza minuta and Trachysurus caelatus are confined to the upper half of the Lagoon and contribute to about $20 \%$ to the total catch. (Table. 1). 
Table. 1. Check list and distribution pattern of fish in the Bolgoda Lagoon.

\begin{tabular}{|c|c|c|c|c|c|c|}
\hline & Family & Species & Distribution & $\begin{array}{l}\text { Salinity } \\
\text { range } \\
(\%)\end{array}$ & $\begin{array}{l}\text { Commercial } \\
\text { importance }\end{array}$ & Habitat \\
\hline 1. & Acunthuridae & Acanthurus galn (Forskal, 1975)) & lower part & $12-33$ & $\begin{array}{l}++ \\
++\end{array}$ & $\mathbf{M}$ \\
\hline 2. & Anguillidae & $\begin{array}{l}\text { i. Annguilla bicolor bicolor } \\
\text { ii. A. nebulosa nebulosa }\end{array}$ & $\begin{array}{l}\text { entire } \\
\text { entire }\end{array}$ & $\begin{array}{l}0.5-34 \\
0.5-34\end{array}$ & $\begin{array}{l}++ \\
++\end{array}$ & $\begin{array}{l}\mathrm{F}, \mathrm{C} \\
\mathrm{F}, \mathrm{C}\end{array}$ \\
\hline 3. & Bagridae & Macrones guliop (H.Buchanan,. 1822) & entire & $0.5-34$ & ++ & $\mathrm{B}, \mathrm{eF}$ \\
\hline 4. & Balonidae & Tylosurus strongylurus (Van hasselt) & lower part & $12-34$ & ++ & $\mathrm{M}, \mathrm{eF} \& \mathrm{~S}$ \\
\hline 5. & Carangidae & $\begin{array}{l}\text { Caranx sansun (Forskal, 1975) } \\
\text { C. melampyqus (cuvier, 1833) }\end{array}$ & $\begin{array}{l}\text { lower } \\
\text { lower }\end{array}$ & $\begin{array}{l}12-34 \\
12-33\end{array}$ & $\begin{array}{l}++ \\
++\end{array}$ & $\begin{array}{l}\mathbf{M} \\
\mathbf{M}\end{array}$ \\
\hline 6. & Chanidae & Chanos chanos (Forskal, 1775) & lower & $13-34$ & ++ & $\mathrm{C}, \mathrm{M}, \mathrm{eB}$ \\
\hline 7. & Cichlidae & $\begin{array}{l}\text { Etroplus suratensis (Bloch, 1785) } \\
\text { E. maculatus (Bloch, 1785) } \\
\text { Oreochromis mosambicus (Bloch, 1785) }\end{array}$ & $\begin{array}{l}\text { middle and } u \\
\text { middle and } u \\
\text { middle and } u\end{array}$ & $\begin{array}{l}0.5-18 \\
0.5-19 \\
0.5-19\end{array}$ & $\begin{array}{l}++ \\
++ \\
++\end{array}$ & $\begin{array}{l}\mathrm{F}, \mathrm{eB} \\
\mathrm{B} \\
\mathrm{F}, \mathrm{eB}\end{array}$ \\
\hline
\end{tabular}


8. Clupeidae

Macrura kelee(cuvier, 1829)

Tenualosa sinensis (Linnaeus, 1758)

Sardinella melanura (Cuvier, 1829)

9. Cyprinidae

Amblypharynaodon melettinus

(Velenciennes, 1844)

Puntius filamentosus (Val, 1844)

Labeo porcellus lankae

(Deraniyagala, 1952)

10. Cyprinodontidae

Aplocheilus lineatus deyi

(Steindachner, 1982)

11. Dorosomidae

12. Dussumieridae

13. Elopidae

14. Gerridae

(Deraniyagala, 1929)

Elops machnata (Forskal, 1775)

Meqalops cyprinoides

(Broussonet, 1782)

Garreomorpha setifer lower

10-34

10-34

13-34

lower

upper

upper

$0.5-8$

$0.5-8$

upper

$0.5-6$

upper

0.5-7

lower and middle $8.0-18$

lower and middle $12-34$

(H.Buchanan, 1822) lower

$0.5-8.0$

upper

$5.0-13$

middle and upper $\quad$ 5-18 $\begin{array}{ll}++ & M \\ - & M \\ ++ & M\end{array}$

F

F, R\&S

F, R

F

B

B, eS

B

B

$++$

B 
15. Gobiidae

Awaous grammepo

(H. Buchanan, 1822)

16. Hemiramphidae

17. Latidae

18. Leiognathidae

19. Lutianidae

20. Monodactylidae

21. Mugillidae

\section{Hyporhamphus qaimarbi}

\section{(Val. 1846)}

Hemirhamphus marqinatus (Forskal,1775)

Lates calcarifer (Bloch,1790)

Secutor ruconius (H.Buchanan,1822)

S. insidiator (Bloch,1787)

L. splendens (Cuvier,1829)

L. daura (Cuvier,1829)

Gazzp minuta (Bloch,1787)

L. smithursti

(Ramsay and Ogilby,1886)

L. dussumieri (Val,1835)

L. fasciatus (Lacepede,1803)

L. brevirostris

(Val,1835)

Lutianus araentimaculatus

(Forska, 1775)

Monodactylus argenteus (Lin, 1758)

Mugil cephalus (Lin, 1758)

Liza oligolepis (Bleeker,1859)

middle and upper

upper

lower and middle

middle and upper 5-18

lower and middle $\quad 8-34$

lower

lower

lower and middle

Lower and middle

lower

lower

entire

lower and middle

entire

lower and middle

lower and middle

entire
0.58

8.34

12-34

-
++
++
++
++
++
+
++
++
++
++
++
++
++

12-34

0.5-34

$12-34$

0.5-34

$0.5-24$
$\bar{N}$

$\mathrm{M}, \mathrm{eL}$

M, eL

$\mathrm{M}, \mathrm{eL}$

M

M

M

M, eL

M

M

$\mathrm{M}$, eL

$\mathrm{M}$, eL

M

M

$\mathrm{M}, \mathrm{eL}$

M

C, B, eF

C, $\mathrm{M}$, eL 
22. Muraenesocidae

23. Ophichthydae

24. Ophiocephalidae

25. Periophthalmidae

26. Plectorhynchidae

27. Scatophagidae

28. Serranidae

29. Sillaginidae

30. Soleidae

31. Tachysuridae

32. Tetraodotidae

33. Theraponidae
Muraenesox cineretss (Forskal,1775) entire

Ophichthys rhytidodermatoides (Bleeker,1852)

Ophiocephalus striatus (Bloch,1793) upper

Periophthalmus koelreuteri (Pallas, 1770)

Gatarin schotaf (Forskal,1775)

Scatophagus argus (Lin,1766)

Epinephalus merra (Bloch,1793)

Sallago sihama (Forskal,1775)

Brachius orientalis (Bloch,1801)

Tachysurus caelatus (Val,1862)

Netuma thalasasimus (Ruppel,1835)

Pseudarius platystomus (Day,1975)

Monotretus cutcutla(H.Buchanan,1822) middle and upper

Austisthes puta (Cuvier,1829)

lower

upper

$\begin{array}{lll}0.5-34 & ++ & \mathrm{B} \\ 0.5-34 & ++ & \mathrm{M}, \mathrm{eL} \\ 0.5-8 & ++ & \mathrm{F}, \mathrm{eL} \\ 0.5-11 & + & \mathrm{B}, \text { eMouth } \\ 18-34 & +- & \mathrm{M} \\ 0.5-11 & ++ & \mathrm{B} \\ 18-34 & ++ & \mathrm{M} \\ 18-34 & ++ & \mathrm{M}, \mathrm{eL} \\ 15-34 & ++ & \mathrm{M}, \mathrm{eL} \\ 0.5-34 & ++ & \mathrm{M}, \mathrm{eL} \\ 11-34 & ++ & \mathrm{M}, \mathrm{eL} \\ 12-34 & - & \mathrm{M}, \mathrm{eL} \\ 0.5-12 & - & \mathrm{F}, \mathrm{eL} \\ 15-34 & - & \mathrm{M}, \mathrm{eL} \\ & & \end{array}$

M, Marine; B, Brackishwater; F, Freshwater; C, Catadromous; eF, enter Freshwater; eS, enter Streams; eB, enter Brackishwater; R, Reservoir; S, Stream; eL, enter Lagoon; eMouth, enter Mouth, + + commercially impt. 


\section{General Comments:}

A total of 55 species of fish belonging to 33 families are present in the Bolgoda Lagoon system which has an area of about 1500 ha. The majority fish $(90 \%)$ are either marine or brackish water species and are mostly confine to the nothern Bolgoda Lake, where the water is brakish during most part of the year. Nalinda (1988) had reported 33 species of fish belonging to 16 families from the Attidiya marsh which is situated around Bolgoda Lagoon. Eleven species of fishes reported in the present study are common to the above marshes as well (Nalinda 1988). Therefore, the total number of species of fish reported so far for the Bolgoda Lagoon and the Attidiya marshes is sixty-seven belonging to 44 families. The above numbers are very high when compared either with the total number of marine species of fish around Sri Lanka or fresh water species of fish in Sri Lanka. there are about 900 species of marine fish belonging to 150 families (Munro, 1954 ; Jinadasa, 1984; Jayanth, 1989) and 64 species of freshwater fishes (Senanayake and Moyle, 1982).

There are about 27 out of the above 55 species of fish which are migratory. Some of these are catadromous, viz. A. bicolor bicolor, A. nebulosa nebulosa, L. oligolepis, M. cephalus and C. chanos.

Other species such as $L$. splendens, $L$. smitjursti and $L$. duss imieri enter the Lagoon and migrate in and out of the Lagoon (Jayanth, 1989). Therefore, barriers and traps constructed across the Lagoon affect their migration pathways. Thus, the recruitment of these species to the Lagoon could be affected.

According to Senanayake and Moyle (1982) the number of fresh water fishes in Sri Lanka are declining due to seven reasons, of which urbanisation, land reclamation and application of chemicals and pesticides are taking place in the Bolgoda Lagoon area. Land reclamation had already taken about 60 ha of marshy land from Attidiya which sustanined the above speices of fish. The annual total fin and shell fish productions from the lagoon with an area of 28000 ha had varied from about $57 \mathrm{mt}$ in 1979 to about $45 \mathrm{mt} 1980$. Thus a steady decline is evident. This could perhaps be attributed to pollution and rise in cost of construction of traps.

\section{Acknowledgements :}

This research was funded out of a grant from the Natural Resources, Energy and Science Authority of Sri Lanka. 
6. References:

Fischer, W. and P.J.P. Whitehead (1940). FAO Identification sheets for fishery purposes, Eastern Idian Ocean (Fishery Area 57) and Western Central Pacific (Fishery Area 71) Vol. 2, FAO, Rome

Jayanth, H.D.S. (1989). The biology and the fishery of Bony fishes in the Bolgoda Lagoon, Sri Lanka. M.Phil. Thesis 289p. Litrary, University of Sri Jayawardenepura

Jinadasa, J. (1984) The age structure, maturity, fishery and the resources of seer (species scomberomorus) in the waters north of Negombo, Proc. Sri Lanka Adv.Sci. 40:55-56.

Munro, I.S.R. (1955). The marine and fresh water fishes of Ceylon. Dept. of External Affairs, Canberra. $351 \mathrm{p}$.

Nalinda, M.A.K. (1988). Checklist of the fishes (pisces) of the Bellanwila-Attidiya marshes. Young Zoologists Association, Occasional papers No.3:1-4

Senanayake, F.R. and P.B. Moyle, (1982). Conservation of fresh fishes of Sri Lanka. Biological Conservation 22:181-1951. 